\title{
An understanding of intervertebral disc development, maturation and cell phenotype provides clues to direct cell-based tissue regeneration therapies for disc degeneration
}

\author{
Ricardo Rodrigues-Pinto • Stephen M. Richardson • \\ Judith A. Hoyland
}

Received: 18 December 2013/Revised: 21 March 2014/ Accepted: 6 April 2014/Published online: 29 April 2014

(C) The Author(s) 2014. This article is published with open access at Springerlink.com

\begin{abstract}
Cell-based regenerative medicine therapies have been proposed for repairing the degenerated intervertebral disc (a major cause of back pain). However, for this approach to be successful, it is essential to characterise the phenotype of its native cells to guarantee that implanted cells differentiate and maintain the correct phenotype to ensure appropriate cell and tissue function. While recent studies have increased our knowledge of the human nucleus pulposus (NP) cell phenotype, their ontogeny is still unclear. The expression of notochordal markers by a subpopulation of adult NP cells suggests that, contrary to previous reports, notochord-derived cells are retained in the adult NP, possibly coexisting with a second population of cells originating from the annulus fibrosus or endplate. It is not known, however, how these two cell populations interact and their specific role(s) in disc homeostasis and disease. In particular, notochordal cells are proposed to
\end{abstract}

R. Rodrigues-Pinto · S. M. Richardson · J. A. Hoyland ( $)$ Faculty of Medical and Human Sciences, Centre for Tissue Injury and Repair, Institute of Inflammation and Repair, University of Manchester, Stopford Building, Oxford Road, Manchester M13 9PT, UK

e-mail: judith.a.hoyland@manchester.ac.uk

R. Rodrigues-Pinto

e-mail: ricardo.rodriguespinto@postgrad.manchester.ac.uk

S. M. Richardson

e-mail: s.richardson@manchester.ac.uk

R. Rodrigues-Pinto

Department of Orthopaedics, Centro Hospitalar

do Porto - Hospital de Santo António,

Largo Prof. Abel Salazar, 4099-001 Porto, Portugal

J. A. Hoyland

NIHR Manchester Musculoskeletal Biomedical Research Unit,

Manchester Academic Health Science Centre, Manchester, UK display both anabolic and protective roles; therefore, they may be the ideal cells to repair the degenerate disc. Thus, understanding the ontogeny of the adult NP cells is paramount, as it will inform the medical and scientific communities as to the ideal phenotype to implant into the degenerate disc and the specific pathways involved in stem cell differentiation towards such a phenotype.

Keywords Intervertebral disc degeneration - Back pain . Nucleus pulposus · Notochordal cells · Notochord · Ontogeny · Phenotype · Mesenchymal stem cells · Regenerative medicine

\section{Introduction}

Back pain is a major international health problem. It is estimated that approximately two-thirds of the world population will experience low back pain at some point in their lives [1], with its point and one-month prevalence being, 11.9 and $23.2 \%$, respectively [2]. With population ageing, the global number of people suffering from this condition will further increase. In an attempt to identify, alleviate and treat it, medicine has developed an armamentarium of diagnostic and therapeutic procedures; their costs, however, together with those associated with work loss, insurance and disability benefits have led to expenditures mounting up to $£ 12$ billion yearly in the UK [3] and $\$ 85.9$ billion in the USA [4]. In the USA alone, between 1997 and 2005, the estimated number of people suffering from back pain increased by $20.7 \%$ which was accompanied by a $65 \%$ increase (adjusted for inflation) in the overall health expenditure to treat this condition [4]. This overwhelming investment, however, has had no significant clinical impact as, during the same period, self-reported measurements of 
mental health, physical functioning, work, school and social limitations among adult patients with back pain have worsened [4]. Thus, an improvement in and development of novel treatment strategies are paramount to tackle such a prevalent and disabling condition.

To date, the pathogenesis of back pain is not completely understood. It is believed to be multifactorial in origin, with factors such as heredity, but also obesity, occupation, smoking, alcohol consumption and diabetes all being implicated to various degrees [5]. Research on the intervertebral disc (IVD) has shown that disc degeneration is associated in around $40 \%$ of cases [6] and has a probable causal relationship with back pain [7].

The intervertebral disc

The IVD is a complex structure that provides flexibility to the vertebral column and sustains the weight applied through the spine. It is formed by the peripheral annulus fibrosus (AF), a ligamentous lamellar structure composed predominantly of type I collagen fibres, which are oriented obliquely between lamellae and inserted into the adjacent upper and lower vertebrae [8]. The vertebrae are covered superiorly and inferiorly by the cartilaginous endplates, which allow for nutrient intake and waste product removal from the largely avascular IVD. The inner part of the AF is characterised by a transition from type I to type II collagen and increased proteoglycan content [8], and circumferentially encloses the nucleus pulposus (NP). The NP is a highly hydrated structure, predominantly composed of the proteoglycan aggrecan, interspersed within an irregular mesh of type II collagen fibres.

Only $1 \%$ of the IVD volume is occupied by its cells [9], but they assume a vital role, as they are responsible for extracellular matrix synthesis and turnover. Outer AF cells are fusiform fibroblast-like, while inner AF cells are more rounded. The cells in the human NP are large and vacuolated in the newborn, but soon after birth they become smaller, round and are typically described as chondrocytelike cells [10].

The pathogenesis of disc degeneration

It is the NP that is thought to be required for generation and maintenance of the disc's structural integrity and is the first structure to be affected during degeneration. NP degeneration is characterised by a cell-driven imbalance between matrix synthesis and degradation [11]. Type II collagen is gradually replaced by type I collagen, which confers a more fibrous nature to this tissue. Proteoglycan synthesis, particularly aggrecan, also decreases. Concurrently, there is an up-regulation of matrix degrading enzymes, namely MMP (matrix metalloproteinases) $-1,-3,-7,-9,-10$ and -13 and ADAMTS (A Disintegrin And Metalloproteinase with Thrombospondin Motifs) $-1,-4,-5,-9$ and -15 [12-14].

Overall, these matrix changes lead to reduced osmotic pressure, reduced hydration and ultimately impaired mechanical function. The NP eventually loses its ability to distribute the compressive forces between the vertebral bodies, which are non-uniformly transferred to the $\mathrm{AF}$, generating areas of increased pressure and risk of microtrauma. This altered force distribution and micro-trauma results in tears and fissures along the AF and ultimately loss of disc height [15]; in advanced stages of degeneration, the NP herniates outwards through the AF fissures and neovessels and nerves grow inwards. Importantly, nerve ingrowth into the usually aneural IVD is implicated in the pain associated with these conditions [7].

Degeneration of the IVD impacts not only on this tissue, but also on the surrounding anatomical structures, such as spinal facets, spinal cord, nerve roots, muscle and ligaments, which further impair IVD function leading to back pain.

Therapies for disc degeneration

Current medical treatments for disc degeneration rely on conservative treatments (non-steroidal anti-inflammatory drugs, opioids and exercise therapy) [5] and, when these fail, on surgery.

Surgical treatments such as spinal fusion and disc replacement have shown satisfactory results in alleviating pain. They are, however, not devoid of complications, including accelerated degeneration of the levels adjacent to the fusion [16] or prosthetic disc's migration, extrusion or failure [17]. Most importantly, these treatments aim to alleviate patient' symptoms, but do not target the underlying disease itself.

Recent progress in tissue engineering and regenerative medicine has increased the interest in developing a biological approach to this condition, through which cells alone or together with biomaterials would be implanted into the NP to both repopulate and stimulate native cells to produce a healthier extracellular matrix.

Autologous NP cell implantation would appear a good solution to repopulate the disc and animal studies have shown it can retard disc degeneration [18, 19], although concerns have been raised by this approach. As the IVD is relatively hypocellular, a single disc would not have sufficient cells for expansion, which would mean harvesting cells from more than one disc. This would be complicated by the fact that the method currently used to harvest disc cells (needle puncture) has been shown to induce degeneration in healthy discs and to accelerate it in degenerate ones [20]. Additionally, degenerate disc cells display 
increased senescence [21, 22], increased expression of matrix catabolic and degrading enzymes [12, 23] and decreased synthesis of matrix components [11, 24], properties that would make them functionally inadequate for transplantation.

Stem cells, particularly adult mesenchymal stem cells, have been proposed as good alternative candidates and there is a growing body of evidence confirming their suitability [25-30]. However, for progenitor cells to be differentiated into the correct phenotype and adequately replace or stimulate the native NP cell population, a complete understanding of the cell or cells populating this tissue is paramount. Recent studies have suggested that, contrary to what was previously thought, notochordal cells persist in the adult human NP, possibly coexisting with other populations of cells. This is particularly important since in vitro and in vivo animal work have suggested that notochordal cells may be the ideal population to repopulate the degenerate NP. This review will highlight recent studies focusing on the ontogeny, development and maturation of the NP cells.

\section{The cell phenotype of the intervertebral disc: lessons from embryology}

\section{NP development within the IVD}

The embryologic origins of the IVD can be traced back to the third week of embryonic development. Early in this week, gastrulation occurs and the inner cell mass adopts a more complex organisation. Gastrulation is a fundamental embryologic phase in animal development during which cells move and rearrange themselves to shape the three germ layers (ectoderm, mesoderm and endoderm) that will give rise to all the tissues and organs in the developing embryo [31]. It is characterised by four distinct movements (epiboly, internalisation, convergence and extension), which are regulated by mechanisms such as cell migration, intercalation, epithelial-mesenchymal transition and cell shape changes [32]. By the end of the third week, the mesoderm, from which most connective tissues originate, undergoes a subdivision into axial mesoderm (notochord), paraxial mesoderm (somites), intermediate mesoderm and lateral plate mesoderm. The notochord and somites will play a fundamental role in the formation of the primitive axial skeleton, with the notochord occupying a midline cranio-caudal location, where it lies ventral to the neural tube, and both having a row of somites on each side (Fig. 1, week 3). Although being mesoderm-derived, due to a process of mesenchymal-epithelial transition, the notochord and somites display epithelioid characteristics such as cell polarity and cell-cell contact [33]. The main functions of the notochord at this stage are to provide longitudinal support to the embryo, to direct the formation of the neural tube from the ectoderm-derived neural plate (neurulation) [34] and to induce paraxial mesoderm segmentation in pairs of cranio-caudally distributed somites (somitogenesis) [35].

During week 4, the embryo enters organogenesis, in which the endoderm-, mesoderm- and ectoderm-derived cells differentiate and start to acquire the distinctive characteristics of the specific tissues and systems they will originate [36]. During this week, the notochord induces the somites to readopt mesenchymal characteristics enabling their cells to migrate: those that migrate peripherally constitute the dermatomyotome-these cells will later form the dermis and muscle; the ones that migrate towards and encircle the notochord and neural tube constitute the sclerotome, which will later form the spinal skeleton [33] (Fig. 1, week 4).

During the remaining weeks of embryonic development (5th-6th week), the migrated sclerotomal cells condense around the notochord, and the dermatomyotomal cells migrate further away from the midline [37] (Fig. 1, weeks 5-6). As notochordal cells contain vacuoles that retain hydrated materials [38], this generates osmotic pressures that further induce elongation of this structure along the midline axis.

By the beginning of week 7 , the sclerotomal cells have a distinct segmented shape with highly condensed cell regions intercalating with looser cell regions. Occupying the most central part along the axis of the foetus is still a continuous row of large vacuolated notochordal cells. Between the seventh and the end of the ninth week, the sclerotomal-derived segments containing the more loosely organised cells will push against the notochord; conversely, the more densely arranged sclerotomal-derived segments expand (becoming even denser) to accommodate the notochord that is being pushed away from the adjacent segments (Fig. 1, weeks 7-9).

After week 10, the segments containing the more loosely organised cells have completely pushed the notochord from their centre and will become the vertebral body (VB); the denser sclerotomal-derived cells have expanded even further and will become the AF, which encircles the notochord-derived NP [37, 39] (Fig. 1, week 10).

After this stage, the main spinal structures have already acquired their characteristic shape, with morphologically distinct chondrocytic vertebral bodies (that will ossify after birth) and IVD, formed by the AF and the notochordal NP. Remnants of notochordal cells within the VB are rare entities that may give rise to a specific type of tumourschordomas [40].

NP cells in the maturing IVD

At birth, the cells within the NP are morphologically similar to those that constitute the embryonic notochord. 
WEEK 3

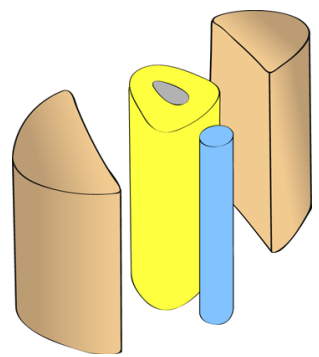

WEEKS 7 - 9

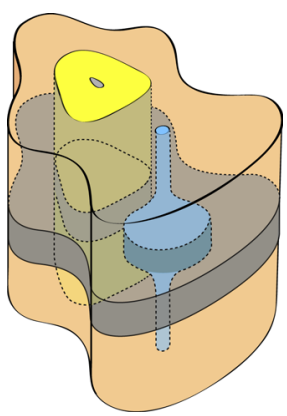

WEEK 4

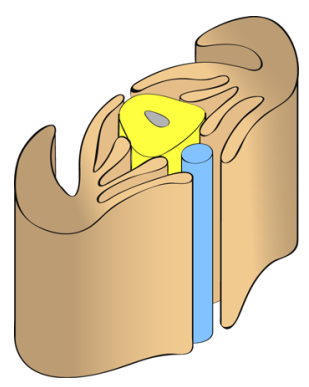

WEEK 10

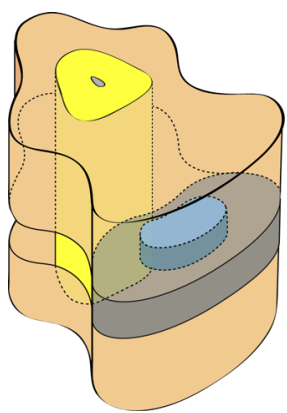

WEEKS 5 - 6

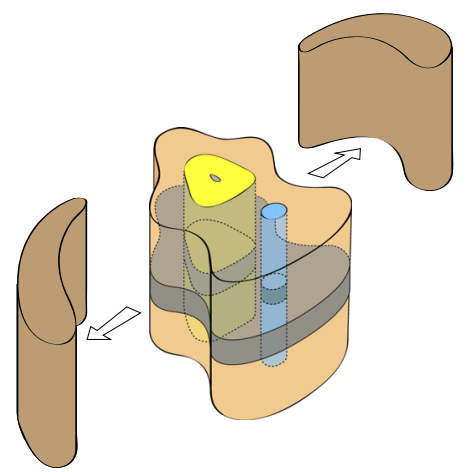

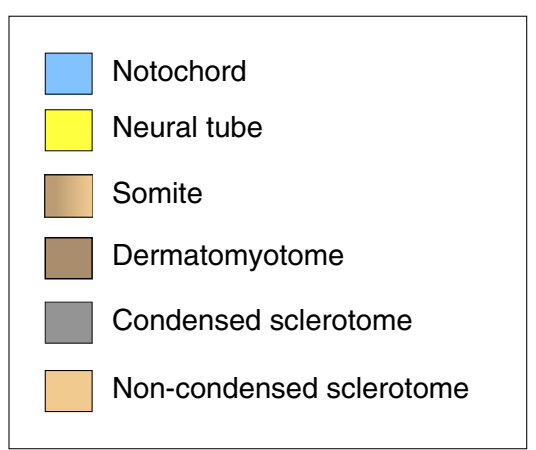

Fig. 1 Development of the spine: third week post-conception (end of) the notochord and the neural tube elongate and occupy a central location along the embryo axis, with a row of somites on each side. Fourth week post-conception (end of) the notochord induces somite cell migration: sclerotomal cells migrate towards the midline and separate from the dermatomyotomal cells, which then migrate to the periphery. 5th-6th week post-conception sclerotomal cells condense around the notochord and neural tube, and dermatomyotomal cells migrate further away to the periphery. 7 th-9th week post-conception sclerotomal cells expand in the VB anlagen region, adopting a non- condensed pattern and pushing notochordal cells away from its centre; in the IVD anlagen, sclerotomal cells condense to accommodate the notochordal cells migrating from the adjacent segments. 10th week post-conception the notochord is restricted to the centre of the IVD anlagen, where it will later form the NP; on its periphery, the condensed sclerotomal cells will become the $\mathrm{AF}$, and in the adjacent segments the non-condensed sclerotomal cells will become the VB. (C) November 2012. Illustration by Sam Goddard, CMFT Clinical Photography \& Medical Illustration Services, Tel: 016127 64671)
They are large $(25-85 \mu \mathrm{m})$ and contain intracellular vacuole-like structures [41]. They usually occur in clusters, have well-demarcated Golgi and "immature" mitochondria associated with large endoplasmic reticulum [41]. Although the content of the vacuoles in the NP cells is not known, it has been hypothesised that, like the cells in the developing notochord, they contain unsecreted proteoglycans [42]. In humans, this population of large vacuolated notochordal cells is reported to decrease during the first decade of life and to have disappeared after that period [10]. There are, however, reports of a small percentage of cells expressing notochordal markers persisting until adult life [43]. At the same time notochordal cells start to disappear, a population of smaller (averaging $10 \mu \mathrm{m}$ in diameter), round and non-vacuolated cells begins to populate the NP, becoming the predominant population of cells after the first decade of life. Owing to the morphological similarities between these cells and articular cartilage (AC) chondrocytes, they have been termed "chondrocyte-like cells" [44] and will be referred to here as small or adult NP cells. The notochordal cell disappearance may occur as a response to the unique microenvironment within the NP, as notochordal cells have been shown to have little resistance to nutrient starvation [45] and compressive loads [46]. This change from notochordal to small NP cells occurs before or soon after birth occurs in humans, cows, sheep, horses and chondrodystrophic dogs; however, other animals, such as pigs, rabbits, non-chondrodystrophic dogs, mice and rat retain the vacuolated morphology of NP cells until much later in life [47].

\section{Ontogeny of the mature NP cell}

The observation that the morphology of the immature cells differs from that of mature cells has given rise to a controversy regarding the origin of the cells populating the 
Table 1 Transcription factors and signalling molecules expressed by cells in the notochordal/immature NP

\begin{tabular}{|c|c|c|}
\hline Gene & Species and identification method & $\begin{array}{l}\text { Description of the protein encoded and relevance to the IVD } \\
\text { biology }\end{array}$ \\
\hline $\begin{array}{l}\text { Noto } \\
\text { (notochord } \\
\text { homeobox) }\end{array}$ & $\begin{array}{l}\text { Mice } \\
\text { Fate-mapping studies (embryonic stages to maturity) (McCann } \\
\text { et al. 2011) }\end{array}$ & $\begin{array}{l}\text { Transcription factor whose expression is restricted to the } \\
\text { organiser node and the nascent notochord during } \\
\text { gastrulation and axis elongation } \\
\text { It regulates node morphogenesis, notochord ciliogenesis and } \\
\text { left-right patterning }\end{array}$ \\
\hline $\begin{array}{l}\text { Shh (sonic } \\
\text { hedgehog) }\end{array}$ & $\begin{array}{l}\text { Mice } \\
\text { Fate-mapping studies (embryonic stages to maturity) [40] }\end{array}$ & $\begin{array}{l}\text { Signalling molecule required for patterning in the early } \\
\text { embryo and that is highly expressed in the embryonic } \\
\text { notochord } \\
\text { It is hypothesised to act in the induction of the floor plate and } \\
\text { in neural tube patterning }\end{array}$ \\
\hline $\mathrm{T}$ (Brachyury) & $\begin{array}{l}\text { Rat } \\
\text { Microarrays (comparison between } 1 \text { and 4-month-old NP and } \\
\text { AF) [76] } \\
\text { Bovine } \\
\text { qRT-PCR (comparison between 18- and 36-month-old large } \\
\text { notochordal and small chondrocyte-like cells) [58] }\end{array}$ & $\begin{array}{l}\text { Embryonic transcription factor regulating the transcription of } \\
\text { genes required for mesoderm formation and differentiation } \\
\text { It is localised to notochord-derived cells where it is thought } \\
\text { to mediate cartilage development in the developing } \\
\text { embryo, and also in chordomas }\end{array}$ \\
\hline
\end{tabular}

mature NP. Some authors' state that notochordal cells die and are replaced by a new population of cells migrating from adjacent tissues [48]. Favouring this hypothesis are the histological observations of rabbit notochordal NP cells being gradually replaced by chondrocytes migrating in a centripetal manner from the endplate [49] or from the AF [48]; chemotactic signals derived from notochordal cells have been implicated as being the driving forces for this migration [50].

Other authors, however, argue that the smaller adult NP cells, despite their distinct morphology are derived from the original population of larger notochordal cells. Indeed, cell size differences are not uncommon in cells with common ancestry where these may be the result of differences in signal variations in RNA/DNA ratios, metabolic activity and cell cycle status, having absolutely no correlation with cell ontology [42]. Thus, adult NP cells may correspond to different stages of maturation of the precursor notochordal cells. This is supported by the observation that cells from chordomas, tumours arising from embryonic notochordal remnants, can differentiate into chondrocyte-like cells, expressing type II collagen and aggrecan [51] and by the in vivo sequential transformation of mouse notochordal cells into smaller chondrocyte-like cells after IVD needle puncture [52].

It was not until recently that this topic was more extensively studied and clarified by fate-mapping studies in mice and by gene expression profiling of the bovine and human NP cells. Choi and colleagues [40] knocked the recombinase cre gene into the sonic hedgehog (Shh) gene in mice. Shh is a protein required for normal NP development and highly expressed in the embryonic notochord.
By mating these mice with reporter mice, and tracking out descendants, the authors identified exclusively notochordal-derived cells within the NP along the whole embryologic period and until maturity [40]. Additionally, McCann and colleagues [53] performed a similar study, but using the gene Noto, a highly conserved transcription factor whose expression is reported to be restricted to the node and the notochord. Noto-cre mice were mated with reporter mice, and the descendant's notochord fate was tracked from embryonic period until adulthood, again demonstrating that the NP in the fully formed mouse IVD is derived from the notochord.

Further supporting a notochordal origin for the adult NP cells is the identification of cytokeratins (KRT) $-8,-18$ and -19 or brachyury, which are known to be expressed by the embryonic notochord [54], and are highly expressed in the NP of the young rat [55], chondrodystrophoid dog [56], adult bovine [57], and both the non-degenerate and degenerate human NP [43, 58, 59]. A further analysis of morphologically different cells separated by size from the bovine NP (small chondrocyte-like and large vacuolated cells) [57, 60], confirmed a significant overlapping gene expression between these two morphologically different cells, including that of brachyury, supporting the theory of a common ancestry.

\section{Cellular heterogeneity in the NP}

Although the findings described in these studies support the existence of notochord-derived cells in the adult NP, which in some species such as humans, have undergone differentiation to morphologically smaller and rounded cells, some recent reports unveil the possibility of this notochord- 
Table 2 Growth factors expressed by cells the notochordal/immature NP

\begin{tabular}{|c|c|c|}
\hline Gene & Species and identification method & $\begin{array}{l}\text { Description of the protein encoded and } \\
\text { relevance to the IVD biology }\end{array}$ \\
\hline $\begin{array}{l}\text { BMP-6 (bone } \\
\text { morphogenetic } \\
\text { protein 6) }\end{array}$ & $\begin{array}{l}\text { Rat } \\
\text { Microarrays (comparison between } \\
\text { 1-month-old NP, 1-month-old AF and } \\
\text { 12-month-old NP) [75] }\end{array}$ & $\begin{array}{l}\text { Belongs to the BMP family of signalling } \\
\text { molecules that are implicated in inducing } \\
\text { bone growth and dorsal axis patterning }\end{array}$ \\
\hline $\begin{array}{l}\text { CTGF } \\
\text { (connective } \\
\text { tissue growth } \\
\text { factor) }\end{array}$ & $\begin{array}{l}\text { Rat } \\
\text { Microarrays (comparison between } \\
\text { 1-month-old NP, 1-month-old AF and } \\
\text { 12-month-old NP) [75] }\end{array}$ & $\begin{array}{l}\text { Cysteine-rich secretory protein that } \\
\text { mediates extracellular matrix interactions } \\
\text { It is secreted by non-chondrodystrophic } \\
\text { dog's notochordal cells and has been } \\
\text { shown to up-regulate proteoglycan } \\
\text { synthesis by small bovine NP cells [84] }\end{array}$ \\
\hline $\begin{array}{l}\text { TGF- } 32 \\
\text { (transforming } \\
\text { growth factor } \\
\text { ß2) }\end{array}$ & $\begin{array}{l}\text { Rat } \\
\text { Microarrays (comparison between } \\
\text { 1-month-old NP, 1-month-old AF and } \\
\text { 12-month-old NP) [75] }\end{array}$ & $\begin{array}{l}\text { Extracellular glycosylated protein. It has a } \\
\text { vital role during embryonic development } \\
\text { and suppresses the effects of interleukin } \\
\text { dependent T cell growth } \\
\text { Its expression in IVD cells (together with } \\
\text { the expression of TGF- } 31 \text {, TGF- } \$ 2 \text { and } \\
\text { their receptors) were shown to decrease } \\
\text { with mice ageing [85] }\end{array}$ \\
\hline
\end{tabular}

derived population of adult NP cells coexisting with another population NP of cells, with a different ontogeny. Gilson and colleagues have shown that the expression of the notochordal gene KRT- 8 in the adult bovine IVD was restricted to a subset cells, found within a morphologically similar population of KRT-8 negative cells [61]. Weiler and colleagues investigated the expression of KRT -8 , -18 and -19 and also galectin-3 (also expressed by the embryonic notochord [62]) in human autopsy NP samples, and found them to be co-expressed by a large percentage of cells in most patients under the age of 30 , but to be restricted to subsets of clustered cells in older patients [63]. Furthermore, and supporting the hypothesis of cells migrating from adjacent tissues into the NP [49], Tanaka and colleagues [64], demonstrated that, by inducing disc degeneration in transgenic mice with GFP-tagged notochordal cells, a population of nonGFP chondrocyte-like cells appeared in the NP.

The identification of tissue-specific mesenchymal stem cells (MSCs) in tissues other than the bone marrow, adipose tissue and umbilical cord, has prompted researchers to investigate their presence within the IVD. Using a panel of markers validated by the International Society for Cell Therapy as bone marrow MSC markers (CD90+, CD73+, CD105+, CD166+, CD45-, CD34-, CD14-, HLA-DR), Risbud and colleagues [65] identified cells within human degenerate discs, that were capable of undergoing differentiation along the chondro-, osteo- and adipogenic lineages, while Blanco and colleagues [66] identified cells capable of chondro and osteogenic differentiation. Using BrdU labelling, Henriksson and colleagues [67] located in vivo a population of progenitor cells in the AF border that showed proliferation in a stem cell niche-like pattern.
More recently, Sakai and colleagues [68] identified a subpopulation of cells within the rat and human NP (characterised by being (Tie2 + and GD2 +), which were shown to be multipotent and to undergo differentiation to both mesenchymal and NP lineages. It remains, however, to be elucidated whether the stem-like cells identified in these studies derive from the embryonic notochord or from the adjacent sclerotomal-derived tissues.

The search for the notochordal cell genetic signature

For the adult human NP to be completely characterised, it would be important that, as with the mice fate-mapping studies, immature notochordal cells were tracked along different stages of development from foetal life until maturity, independently of the morphology they assume at those different stages. This would allow an understanding of the different cell populations coexisting in the NP and their ontogeny.

Additionally, there is a growing body of evidence supporting a positive role for notochordal cells in the IVD. Notochordal cells have been shown to produce more proteoglycans than smaller NP cells [69] and, when in coculture, notochordal cells interact with small NP cells stimulating them to produce a healthier extracellular matrix [70, 71]. Recent findings also show that notochordal cells can prevent Il-1-induced cell death in small NP cells [72]. Therefore, defining the notochordal cell phenotype and tracking these cells in human discs would also allow clarifying their role in the disc's physiology and disease. If, as evidence suggests, notochordal cells are the ideal cells to repopulate/regenerate the degenerate IVD, a definition of 
Table 3 Cell surface markers expressed by cells in the notochordal/immature NP

\begin{tabular}{|c|c|c|}
\hline Gene & Species and identification method & $\begin{array}{l}\text { Description of the protein encoded and relevance to the IVD } \\
\text { biology }\end{array}$ \\
\hline $\begin{array}{l}\mathrm{N}-\mathrm{Cad} / \mathrm{CDH} 2(\mathrm{~N}- \\
\text { Cadherin/Cadherin 2) }\end{array}$ & $\begin{array}{l}\text { Bovine } \\
\text { qRT-PCR (comparison between 18- and } \\
36 \text {-month-old large notochordal and small } \\
\text { chondrocyte-like cells) [58] } \\
\text { Rat } \\
\text { Microarrays (comparison between 3-month-old } \\
\text { NP, AF and costal cartilage) [73] }\end{array}$ & $\begin{array}{l}\text { Calcium dependent cell-cell adhesion glycoprotein expressed } \\
\text { during gastrulation and that is required for the establishment } \\
\text { of neuronal polarity }\end{array}$ \\
\hline $\mathrm{CD} 24$ & $\begin{array}{l}\text { Human } \\
\text { qPCR, immunofluorescence and flow cytometry } \\
\text { (comparison between adolescent and adult NP) } \\
\text { [79] }\end{array}$ & $\begin{array}{l}\text { Cell surface protein expressed by mature granulocytes and many } \\
\text { B cells } \\
\text { It is highly expressed by chordomas, but not by } \\
\text { chondrosarcomas [86] }\end{array}$ \\
\hline $\begin{array}{l}\text { CD54/ICAM1 } \\
\text { (intercellular adhesion } \\
\text { molecule 1) }\end{array}$ & $\begin{array}{l}\text { Human } \\
\text { qPCR, immunofluorescence and flow cytometry } \\
\text { (comparison between adolescent and adult NP) } \\
\text { [79] }\end{array}$ & $\begin{array}{l}\text { Cell surface glycoprotein expressed by endothelial cells and } \\
\text { cells of the immune system } \\
\text { In cultured IVD cells, its expression is up-regulated by the } \\
\text { exposure to IL-17, IFN } \gamma \text {, and TNF } \alpha \text { [87] }\end{array}$ \\
\hline $\begin{array}{l}\text { CD55/DAF (decay } \\
\text { accelerating factor for } \\
\text { complement) }\end{array}$ & $\begin{array}{l}\text { Rat } \\
\text { Microarrays (comparison between 3-month-old } \\
\mathrm{NP}, \mathrm{AF} \text { and costal cartilage) [73] } \\
\text { Human } \\
\text { Comparison between adult NP, AC and AF } \\
\text { (Hoyland et al. unpublished data) }\end{array}$ & $\begin{array}{l}\text { Membrane protein involved in the regulation of the complement } \\
\text { cascade, which is broadly distributed among hematopoietic } \\
\text { and non-hematopoietic cells }\end{array}$ \\
\hline $\begin{array}{l}\text { IGF1R/CD221 } \\
\text { (insulin-like growth } \\
\text { factor } 1 \text { receptor) }\end{array}$ & $\begin{array}{l}\text { Human } \\
\text { qPCR, immunofluorescence and flow cytometry } \\
\text { (comparison between adolescent and adult NP) } \\
\text { [79] }\end{array}$ & $\begin{array}{l}\text { Receptor for insulin-like growth factor, which has been found } \\
\text { overexpressed in malignant tissues where it functions as an } \\
\text { anti-apoptotic agent by enhancing cell survival } \\
\text { It is expressed by human adult NP and inner AF cells in both } \\
\text { non-degenerate and degenerate disc [88]. A single nucleotide } \\
\text { polymorphism in its gene has been associated with disc } \\
\text { degeneration [89] }\end{array}$ \\
\hline $\begin{array}{l}\text { Integrin subunits } \alpha 1 \text { and } \\
\alpha 6\end{array}$ & $\begin{array}{l}\text { Porcine } \\
\text { Flow cytometry (comparison between sorted large } \\
\text { and more granular and smaller and less granular } \\
\text { NP cells) }\end{array}$ & $\begin{array}{l}\text { Integrins and CD } 239 \text { are expressed by NP cells and are } \\
\text { responsible for their adhesion to laminins }[74,77]\end{array}$ \\
\hline $\begin{array}{l}\text { Integrin subunits } \alpha 3, \alpha 6 \\
\text { and } \beta 4) \\
\text { CD239 }\end{array}$ & $\begin{array}{l}\text { Porcine, rat and human } \\
\text { immunohistochemistry and flow cytometry } \\
\text { (comparison between immature NP and AF } \\
\text { cells) }\end{array}$ & \\
\hline
\end{tabular}

the notochordal phenotype would also be essential for stem cell-based therapies.

For this to be possible, a comprehensive phenotypic characterization of notochordal cells, and especially of markers specific to the notochordal cells in the human IVD would be required. To date, several attempts have been made to identify notochordal markers, either by comparing the gene expression of immature notochordal rat NP with its costal cartilage [73], rat NP tissue with different degrees of maturity [74-76], comparing immature pig NP with AF cells [74, 77], sorted large and granular with smaller, less granular pig NP cells [78], immature human NP with AF cells [74] or NP from human juvenile scoliotic and adult discs [79] (Tables 1, 2, 3, 4 list putative notochordal/ immature NP markers identified in different species and describe their relevance to the IVD field). Proposed rat notochordal markers identified in these studies were CD55 [73], brachyury, neuropilin (Nrp-1), CD221, BASP-1 [76], N-Cad [73, 76], TGF- $\beta$, BMP-6 and CTGF [75]. Proposed human young markers were CD24, CD54 and brachyury [79]. CD90 was not expressed either in immature rat [76] or in scoliotic juvenile NP [79] and has been proposed as a negative notochordal cell marker. Limitations to these studies are the use of animal models, which may not be representative of the human intervertebral disc phenotype and the use of scoliotic discs as a source of human immature NP, as the scoliotic IVD, although derived from young patients, is prematurely degenerated and subjected 
Table 4 Intracellular proteins expressed by cells in the notochordal/immature NP

\begin{tabular}{|c|c|c|}
\hline Gene & Species and identification method & $\begin{array}{l}\text { Description of the protein encoded and relevance to the IVD } \\
\text { biology }\end{array}$ \\
\hline $\begin{array}{l}\text { BASP1 (brain abundant, } \\
\text { membrane-attached } \\
\text { signal protein) }\end{array}$ & $\begin{array}{l}\text { Rat } \\
\text { Microarrays (comparison between 1- and } \\
\text { 4-month-old NP and AF) [76] } \\
\text { Bovine } \\
\text { qRT-PCR (comparison between 18- and } \\
\text { 36-month-old large notochordal and small } \\
\text { chondrocyte-like cells) [58] }\end{array}$ & $\begin{array}{l}\text { Membrane-bound protein initially described as being specific } \\
\text { to neuronal and spinal cord cells, where it participates in } \\
\text { neurite outgrowth and synaptic plasticity, but later found to } \\
\text { be also expressed by human endothelium, developing } \\
\text { mammary gland, kidney, testis, and lymphoid tissues }\end{array}$ \\
\hline Nrp-1 (neuropilin) & $\begin{array}{l}\text { Rat } \\
\text { Microarrays (comparison between 1-4 month-old } \\
\text { NP and AF) [76] }\end{array}$ & $\begin{array}{l}\text { Transmembrane glycoprotein involved in neuronal guidance } \\
\text { and angiogenesis } \\
\text { This ligand, together with its receptor (semaphorin) is highly } \\
\text { expressed in the healthy human NP, but decreases with } \\
\text { degeneration, having therefore been proposed to act as } \\
\text { barriers to neuronal ingrowth in the healthy IVD [90] }\end{array}$ \\
\hline KRT 8 (cytokeratin 8) & $\begin{array}{l}\text { Bovine } \\
\text { qRT-PCR (comparison between 18- and } \\
\text { 36-month-old large notochordal and small } \\
\text { chondrocyte-like cells) [58] }\end{array}$ & $\begin{array}{l}\text { Cytokeratins are typically expressed by epithelial cells, but are } \\
\text { found in a wide range of tissues including the developing } \\
\text { notochord } \\
\text { KRT } 8 \text { is involved in maintaining cellular structural integrity } \\
\text { and in signal transduction and cellular differentiation }\end{array}$ \\
\hline KR I I8 (cytokeratın 18) & $\begin{array}{l}\text { qRT-PCR (comparison between 18- and } \\
36 \text {-month-old large notochordal and small } \\
\text { chondrocyte-like cells) [58] } \\
\text { Human } \\
\text { Immunohistochemistry (comparison between } \\
\text { foetal to mature NP). [63] }\end{array}$ & $\begin{array}{l}\text { KRT } 18 \text { typically dimerises with KRT } 8 \text { to form an intermediate } \\
\text { filament in simple single-layered epithelial cells } \\
\text { KRT19 is the smallest known acidic cytokeratin. It is found in } \\
\text { the periderm, a transient structure that functions as a } \\
\text { protective layer for the embryonic skin } \\
\text { Keratins } 8 \text { and } 18 \text { are involved in resistance against TNF- }\end{array}$ \\
\hline KRT 19 (cytokeratin 19) & $\begin{array}{l}\text { Bovine } \\
\text { qRT-PCR (comparison between 18- and } \\
36 \text {-month-old large notochordal and small } \\
\text { chondrocyte-like cells) [58] } \\
\text { Human } \\
\text { Immunohistochemistry (comparison between } \\
\text { foetal to mature NP) [63] }\end{array}$ & $\begin{array}{l}\text { alpha is implicated in nerve in the ingrowth into the IVD [92], } \\
\text { and hence in back pain pathogenesis [7], they may act as } \\
\text { regulators of this ingrowth } \\
\text { Since intermediate filaments are usually present in cells } \\
\text { subjected to mechanical stress it is possible that, in the IVD, } \\
\text { these proteins act to withstand the hydrostatic pressures in the } \\
\text { NP [10] }\end{array}$ \\
\hline $\begin{array}{l}\text { Laminin (LM511, } \\
\text { LM322) }\end{array}$ & $\begin{array}{l}\text { Porcine } \\
\text { Differences in cell attachment, spreading and } \\
\text { adhesion strength between immature pig NP } \\
\text { and AF cells }\end{array}$ & $\begin{array}{l}\text { Lamins are heterodimeric proteins involved in cell adhesion, } \\
\text { migration, proliferation, differentiation and survival }[74,77]\end{array}$ \\
\hline
\end{tabular}

to abnormal environmental (load) stresses which may impact on their gene expression profiles [80, 81].

Interestingly, results from microarray studies in our group confirm the presence of some of these proposed immature genes both in mature bovine and adult human NP. N-cadherin was identified as a bovine and human NP marker and BASP-1 as a bovine and human IVD marker, with its gene expression decreasing with degeneration [57, 58]. Unpublished data from our group also indicate CD55 as a putative NP marker (50-fold higher differential expression in NP compared to AF or AC). This, together with the differing expression of these genes between immature and mature rat NP, could represent a notochordal, immature NP phenotype marker common to the three species, irrespective of cell morphology. Moreover, since genes known to be expressed by the embryonic notochord (KRT-8, KRT-18, KRT-19, Gal-3 and brachyury) are also expressed in the adult NP, particularly by subsets of cells, these may represent markers of notochordderived cells in the human adult NP.

We speculate that one or a combination of some of these notochordal markers will be specific to notochord-derived cells, independent of their morphology, maturation or disease state. Its/their identification will allow investigators to track and possibly isolate and study the function of notochordderived cells from discs at those different maturation and disease states. This, in turn, will allow a more thorough understanding, at the molecular level, of the fate and role of notochordal or notochord-derived cells in the IVD and provide further insight into ways to tackle disc degeneration. 


\section{Pending questions and potential clinical implications}

Overall, current data suggest that the adult NP may contain two different populations of cells: one that is notochord derived, and another which is derived from cells migrating from adjacent tissues, possibly the AF; and that in some species, such as the human, both populations of cells have acquired a similar chondrocyte-like morphology due to the unique microenvironment in which they reside.

These findings have implications for understanding NP development, maturation, and disc degeneration. The exact function of these two populations of cells within the disc remains to be explained. If, as suggested by Tanaka and colleagues [64], the migration of cells occurs as a response to a mechanical insult inducing degeneration, what is the exact role of these migrating cells? Are they part of the degenerative process or an attempt to repair?

Additionally, the notochordal cell "loss" from the NP has been historically implicated in the degenerative process. The reasons for this are based on observations of human post-mortem disc samples, where the occurrence of the histological signs of disc degeneration correlates with the disappearance of those cells, and also in the fact that chondrodystrophic dogs develop spinal disorders and disc herniations, whereas non-chondrodystrophic dogs (in which notochordal cells are retained) are resistant to these degenerative disc diseases [41, 70, 82, 83]. This concept is further supported by the aforementioned anabolic and protective role these cells have shown to have in the IVD and its cells. If notochordal cells have such a positive effect in the IVD, is it lost upon this cell morphology change?

It will also be important to understand why this morphology change is restricted to some animal species, such as the human, but does not occur in other animals. If, as postulated above, cell morphology does not reflect cell ontogeny in the adult NP, as cells from different origins can display a similar morphology, possibly the chondrocyte-like morphology reflects the unique physio/chemical microenvironment in which the cells reside. In this way, it may be that the NP niche is responsible for the differentiation of both the large vacuolated notochord-derived cells and the fibroblastic AF-derived cells to the deceivingly homogeneous population of small round chondrocyte-like cells in the adult NP.

Answers to these and other questions will help to understand fundamental biological processes acting on this complex structure from the foetal stage until maturity and also through degeneration. Most attempts to repair or regenerate the NP aim at repopulating this tissue with cells capable of producing a healthier extracellular matrix themselves or of stimulating resident cells. Improved understanding of the ontogeny of the human adult NP cells will inform regenerative medicine as to which cell(s) or which microenvironmental modifications to pursue.

Acknowledgments The authors would like to acknowledge Mr. Sam Goddard for the illustrations in Figs. 1 and 2 (C) November 2012. Illustration by Sam Goddard, CMFT Clinical Photography \& Medical Illustration Services, Tel: 016127 64671). Ricardo Rodrigues-Pinto is supported by a grant from the Programme for Advanced Medical Education, sponsored by Fundação Calouste Gulbenkian, Fundação Champalimaud, Ministério da Saúde, Fundação para a Ciência e Tecnologia and Apifarma, Portugal. The Research Councils UK (RCUK) is acknowledged for funding a fellowship to SMR.

Conflict of interest The authors declare that they have no competing interests.

Open Access This article is distributed under the terms of the Creative Commons Attribution License which permits any use, distribution, and reproduction in any medium, provided the original author(s) and the source are credited.

\section{References}

1. Deyo RA, Weinstein JN (2001) Low back pain. N Engl J Med 344(5):363-370. doi:10.1056/NEJM200102013440508

2. Hoy D, Bain C, Williams G, March L, Brooks P, Blyth F, Woolf A, Vos T, Buchbinder R (2012) A systematic review of the global prevalence of low back pain. Arthritis Rheum 64(6):2028-2037. doi:10.1002/art.34347

3. Maniadakis N, Gray A (2000) The economic burden of back pain in the UK. Pain 84(1):95-103 S0304-3959(99)00187-6

4. Martin BI, Deyo RA, Mirza SK, Turner JA, Comstock BA, Hollingworth W, Sullivan SD (2008) Expenditures and health status among adults with back and neck problems. JAMA 299(6):656-664. doi:10.1001/jama.299.6.656

5. Balague F, Mannion AF, Pellise F, Cedraschi C (2012) Nonspecific low back pain. Lancet 379(9814):482-491. doi:10.1016/ S0140-6736(11)60610-7

6. Cheung KM, Karppinen J, Chan D, Ho DW, Song YQ, Sham P, Cheah KS, Leong JC, Luk KD (2009) Prevalence and pattern of lumbar magnetic resonance imaging changes in a population study of one thousand forty-three individuals. Spine (Phila Pa 1976) 34(9):934-940. doi:10.1097/BRS.0b013e3181a01b3f

7. Freemont AJ, Peacock TE, Goupille P, Hoyland JA, O'Brien J, Jayson MI (1997) Nerve ingrowth into diseased intervertebral disc in chronic back pain. Lancet 350(9072):178-181

8. Humzah MD, Soames RW (1988) Human intervertebral disc: structure and function. Anat Rec 220(4):337-356. doi:10.1002/ar. 1092200402

9. Anderson DG, Albert TJ, Fraser JK, Risbud M, Wuisman P, Meisel HJ, Tannoury C, Shapiro I, Vaccaro AR (2005) Cellular therapy for disc degeneration. Spine (Phila Pa 1976) 30((17 Suppl)):14-19

10. Hunter CJ, Matyas JR, Duncan NA (2003) The notochordal cell in the nucleus pulposus: a review in the context of tissue engineering. Tissue Eng 9(4):667-677. doi:10.1089/107632703768 247368

11. Sive JI, Baird P, Jeziorsk M, Watkins A, Hoyland JA, Freemont AJ (2002) Expression of chondrocyte markers by cells of normal and degenerate intervertebral discs. Mol Pathol 55(2):91-97

12. Le Maitre CL, Freemont AJ, Hoyland JA (2004) Localization of degradative enzymes and their inhibitors in the degenerate human intervertebral disc. J Pathol 204(1):47-54. doi:10.1002/path.1608 
13. Pockert AJ, Richardson SM, Le Maitre CL, Lyon M, Deakin JA, Buttle DJ, Freemont AJ, Hoyland JA (2009) Modified expression of the ADAMTS enzymes and tissue inhibitor of metalloproteinases 3 during human intervertebral disc degeneration. Arthritis Rheum 60(2):482-491. doi:10.1002/art.24291

14. Richardson SM, Doyle P, Minogue BM, Gnanalingham K, Hoyland JA (2009) Increased expression of matrix metalloproteinase-10, nerve growth factor and substance $\mathrm{P}$ in the painful degenerate intervertebral disc. Arthritis Res Ther 11(4):R126. doi:10.1186/ar2793

15. Videman T, Nurminen M (2004) The occurrence of anular tears and their relation to lifetime back pain history: a cadaveric study using barium sulfate discography. Spine (Phila $\mathrm{Pa}$ 1976) 29(23):2668-2676

16. Lund T, Oxland TR (2011) Adjacent level disk disease-is it really a fusion disease? Orthop Clin North Am 42(4):529-541. doi:10.1016/j.ocl.2011.07.006

17. Errico TJ (2005) Lumbar disc arthroplasty. Clin Orthop Relat Res 435:106-117

18. Hohaus C, Ganey TM, Minkus Y, Meisel HJ (2008) Cell transplantation in lumbar spine disc degeneration disease. Eur Spine $\mathbf{J}$ 17(Suppl 4):492-503. doi:10.1007/s00586-008-0750-6

19. Meisel HJ, Siodla V, Ganey T, Minkus Y, Hutton WC, Alasevic OJ (2007) Clinical experience in cell-based therapeutics: disc chondrocyte transplantation a treatment for degenerated or damaged intervertebral disc. Biomol Eng 24(1):5-21. doi:10. 1016/j.bioeng.2006.07.002

20. Carragee EJ, Don AS, Hurwitz EL, Cuellar JM, Carrino JA, Herzog R (2009) 2009 ISSLS Prize Winner: Does discography cause accelerated progression of degeneration changes in the lumbar disc: a ten-year matched cohort study. Spine (Phila Pa 1976) 34(21):2338-2345. doi:10.1097/BRS.0b013e3181ab5432

21. Le Maitre CL, Freemont AJ, Hoyland JA (2007) Accelerated cellular senescence in degenerate intervertebral discs: a possible role in the pathogenesis of intervertebral disc degeneration. Arthritis Res Ther 9(3):R45. doi:10.1186/ar2198

22. Roberts S, Evans EH, Kletsas D, Jaffray DC, Eisenstein SM (2006) Senescence in human intervertebral discs. Eur Spine J 15(Suppl 3):312-316. doi:10.1007/s00586-006-0126-8

23. Le Maitre CL, Freemont AJ, Hoyland JA (2005) The role of interleukin-1 in the pathogenesis of human intervertebral disc degeneration. Arthritis Res Ther 7(4):732-745. doi:10.1186/ ar1732

24. Pearce RH, Grimmer BJ, Adams ME (1987) Degeneration and the chemical composition of the human lumbar intervertebral disc. J Orthop Res 5(2):198-205. doi:10.1002/jor.1100050206

25. Henriksson HB, Svanvik T, Jonsson M, Hagman M, Horn M, Lindahl A, Brisby (2009) Transplantation of human mesenchymal stems cells into intervertebral discs in a xenogeneic porcine model. Spine (Phila Pa 1976) 34(2):141-148. doi:10.1097/BRS. 0b013e31818f8c20

26. Richardson SM, Curran JM, Chen R, Vaughan-Thomas A, Hunt JA, Freemont AJ, Hoyland JA (2006) The differentiation of bone marrow mesenchymal stem cells into chondrocyte-like cells on poly-L-lactic acid (PLLA) scaffolds. Biomaterials 27(22):40694078. doi:10.1016/j.biomaterials.2006.03.017

27. Richardson SM, Hughes N, Hunt JA, Freemont AJ, Hoyland JA (2008) Human mesenchymal stem cell differentiation to NP-like cells in chitosan-glycerophosphate hydrogels. Biomaterials 29(1):85-93. doi:10.1016/j.biomaterials.2007.09.018

28. Risbud MV, Albert TJ, Guttapalli A, Vresilovic EJ, Hillibrand AS, Vaccaro AR, Shapiro IM (2004) Differentiation of mesenchymal stem cells towards a nucleus pulposus-like phenotype in vitro: implications for cell-based transplantation therapy. Spine (Phila Pa 1976) 29(23):2627-2632
29. Stoyanov JV, Gantenbein-Ritter B, Bertolo A, Aebli N, Baur M, Alini M, Grad S (2011) Role of hypoxia and growth and differentiation factor-5 on differentiation of human mesenchymal stem cells towards intervertebral nucleus pulposus-like cells. Eur Cell Mater 21:533-547

30. Strassburg S, Hodson NW, Hill PI, Richardson SM, Hoyland JA (2012) Bi-directional exchange of membrane components occurs during co-culture of mesenchymal stem cells and nucleus pulposus cells. PLoS One 7(3):e33739. doi:10.1371/journal.pone. 0033739

31. Nakaya Y, Sheng G (2008) Epithelial to mesenchymal transition during gastrulation: an embryological view. Dev Growth Differ 50(9):755-766. doi:10.1111/j.1440-169X.2008.01070.x

32. Solnica-Krezel L, Sepich DS (2012) Gastrulation: making and shaping germ layers. Annu Rev Cell Dev Biol 28:687-717. doi:10.1146/annurev-cellbio-092910-154043

33. Hay ED (2005) The mesenchymal cell, its role in the embryo, and the remarkable signaling mechanisms that create it. Dev Dyn 233(3):706-720. doi:10.1002/dvdy.20345

34. Greene ND, Copp AJ (2009) Development of the vertebrate central nervous system: formation of the neural tube. Prenat $\mathrm{Di}-$ agn 29(4):303-311. doi:10.1002/pd.2206

35. Mead TJ, Yutzey KE (2012) Notch signaling and the developing skeleton. Adv Exp Med Biol 727:114-130. doi:10.1007/978-14614-0899-4_9

36. Muller F, O'Rahilly R (2004) The primitive streak, the caudal eminence and related structures in staged human embryos. Cells Tissues Organs 177(1):2-20. doi:10.1159/000078423

37. Peacock A (1951) Observations on the prenatal development of the intervertebral disc in man. J Anat 85(3):260-274

38. Stemple DL (2005) Structure and function of the notochord: an essential organ for chordate development. Development 132(11):2503-2512. doi:10.1242/dev.01812

39. Aszodi A, Chan D, Hunziker E, Bateman JF, Fassler R (1998) Collagen II is essential for the removal of the notochord and the formation of intervertebral discs. J Cell Biol 143(5):1399-1412

40. Choi KS, Cohn MJ, Harfe BD (2008) Identification of nucleus pulposus precursor cells and notochordal remnants in the mouse: implications for disk degeneration and chordoma formation. Dev Dyn 237(12):3953-3958. doi:10.1002/dvdy.21805

41. Hunter CJ, Matyas JR, Duncan NA (2004) The functional significance of cell clusters in the notochordal nucleus pulposus: survival and signaling in the canine intervertebral disc. Spine (Phila Pa 1976) 29(10):1099-1104

42. Risbud MV, Schaer TP, Shapiro IM (2010) Toward an understanding of the role of notochordal cells in the adult intervertebral disc: from discord to accord. Dev Dyn 239(8):2141-2148. doi:10. 1002/dvdy. 22350

43. Stosiek P, Kasper M, Karsten U (1988) Expression of cytokeratin and vimentin in nucleus pulposus cells. Differentiation 39(1):78-81

44. Urban JP, Roberts S (1995) Development and degeneration of the intervertebral discs. Mol Med Today 1(7):329-335

45. Guehring T, Wilde G, Sumner M, Grunhagen T, Karney GB, Tirlapur UK, Urban JP (2009) Notochordal intervertebral disc cells: sensitivity to nutrient deprivation. Arthritis Rheum 60(4):1026-1034. doi:10.1002/art.24407

46. Guehring T, Nerlich A, Kroeber M, Richter W, Omlor GW (2010) Sensitivity of notochordal disc cells to mechanical loading: an experimental animal study. Eur Spine J 19(1):113-121. doi:10.1007/s00586-009-1217-0

47. Miyazaki T, Kobayashi S, Takeno K, Meir A, Urban J, Baba H (2009) A phenotypic comparison of proteoglycan production of intervertebral disc cells isolated from rats, rabbits, and bovine tails; which animal model is most suitable to study tissue 
engineering and biological repair of human disc disorders? Tissue Eng Part A 15(12):3835-3846. doi:10.1089/ten.tea.2009.0250

48. Butler (1989) Comparative anatomy and development of the mammalian disc. In: G P (ed) The biology of the intervertebral disc. CRC Press, Boca Raton, pp 83-108

49. Kim KW, Lim TH, Kim JG, Jeong ST, Masuda K, An HS (2003) The origin of chondrocytes in the nucleus pulposus and histologic findings associated with the transition of a notochordal nucleus pulposus to a fibrocartilaginous nucleus pulposus in intact rabbit intervertebral discs. Spine (Phila Pa 1976) 28(10):982-990. doi:10.1097/01.BRS.0000061986.03886.4F

50. Kim KW, Ha KY, Lee JS, Nam SW, Woo YK, Lim TH, An HS (2009) Notochordal cells stimulate migration of cartilage end plate chondrocytes of the intervertebral disc in in vitro cell migration assays. Spine J 9(4):323-329. doi:10.1016/j.spinee. 2008.05.003

51. Gottschalk D, Fehn M, Patt S, Saeger W, Kirchner T, Aigner T (2001) Matrix gene expression analysis and cellular phenotyping in chordoma reveals focal differentiation pattern of neoplastic cells mimicking nucleus pulposus development. Am J Pathol 158(5):1571-1578. doi:10.1016/S0002-9440(10)64111-9

52. Yang F, Leung VY, Luk KD, Chan D, Cheung KM (2009) Injuryinduced sequential transformation of notochordal nucleus pulposus to chondrogenic and fibrocartilaginous phenotype in the mouse. J Pathol 218(1):113-121. doi:10.1002/path.2519

53. McCann MR, Tamplin OJ, Rossant J, Seguin CA (2012) Tracing notochord-derived cells using a Noto-cre mouse: implications for intervertebral disc development. Dis Model Mech 5(1):73-82. doi: $10.1242 / \mathrm{dmm} .008128$

54. Gotz W, Kasper M, Fischer G, Herken R (1995) Intermediate filament typing of the human embryonic and fetal notochord. Cell Tissue Res 280(2):455-462

55. Lee CR, Sakai D, Nakai T, Toyama K, Mochida J, Alini M, Grad S (2007) A phenotypic comparison of intervertebral disc and articular cartilage cells in the rat. Eur Spine J 16(12):2174-2185. doi:10.1007/s00586-007-0475-y

56. Sakai D, Nakai T, Mochida J, Alini M, Grad S (2009) Differential phenotype of intervertebral disc cells: microarray and immunohistochemical analysis of canine nucleus pulposus and anulus fibrosus. Spine (Phila Pa 1976) 34(14):1448-1456. doi:10.1097/ BRS.0b013e3181a55705

57. Minogue BM, Richardson SM, Zeef LA, Freemont AJ, Hoyland JA (2010) Transcriptional profiling of bovine intervertebral disc cells: implications for identification of normal and degenerate human intervertebral disc cell phenotypes. Arthritis Res Ther 12(1):R22. doi:10.1186/ar2929

58. Minogue BM, Richardson SM, Zeef LA, Freemont AJ, Hoyland JA (2010) Characterization of the human nucleus pulposus cell phenotype and evaluation of novel marker gene expression to define adult stem cell differentiation. Arthritis Rheum 62(12):3695-3705. doi:10.1002/art.27710

59. Rutges J, Creemers LB, Dhert W, Milz S, Sakai D, Mochida J, Alini M, Grad S (2010) Variations in gene and protein expression in human nucleus pulposus in comparison with annulus fibrosus and cartilage cells: potential associations with aging and degeneration. Osteoarthritis Cartilage 18(3):416-423. doi:10.1016/j. joca.2009.09.009

60. Rodrigues-Pinto R, Richardson S, Hoyland JA (2013) Identification of novel Nucleus Pulposus markers: Interspecies variations and implications for cell-based therapies for intervertebral disc degeneration. Bone Joint Res 2(8):169-178. doi:10.1302/20463758.28.2000184

61. Gilson A, Dreger M, Urban JP (2010) Differential expression level of cytokeratin 8 in cells of the bovine nucleus pulposus complicates the search for specific intervertebral disc cell markers. Arthritis Res Ther 12(1):R24. doi:10.1186/ar2931
62. Gotz W, Kasper M, Miosge N, Hughes RC (1997) Detection and distribution of the carbohydrate binding protein galectin-3 in human notochord, intervertebral disc and chordoma. Differentiation 62(3):149-157. doi:10.1046/j.1432-0436.1997.6230149.x

63. Weiler C, Nerlich AG, Schaaf R, Bachmeier BE, Wuertz K, Boos N (2010) Immunohistochemical identification of notochordal markers in cells in the aging human lumbar intervertebral disc. Eur Spine J 19(10):1761-1770. doi:10.1007/s00586-010-1392-z

64. Tanaka M, Sakai D, Hiyama A, Arai F, Nakajima D, Yokoyama K, Mochida J (2012) Evidence of nonnotochordal origin in chondrocyte-like cells of the nucleus pulposus appearing in early stage disk degeneration in the mouse model. Global Spine J. doi:10.1055/s-0032-1319861

65. Risbud MV, Guttapalli A, Tsai TT, Lee JY, Danielson KG, Vaccaro AR, Albert TJ, Gazit Z, Gazit D, Shapiro IM (2007) Evidence for skeletal progenitor cells in the degenerate human intervertebral disc. Spine (Phila Pa 1976) 32(23):2537-2544. doi:10.1097/BRS.0b013e318158dea6

66. Blanco JF, Graciani IF, Sanchez-Guijo FM, Muntion S, Hernandez-Campo P, Santamaria C, Carrancio S, Barbado MV, Cruz G, Gutierrez-Cosio S, Herrero C, San Miguel JF, Brinon JG, del Canizo MC (2010) Isolation and characterization of mesenchymal stromal cells from human degenerated nucleus pulposus: comparison with bone marrow mesenchymal stromal cells from the same subjects. Spine (Phila Pa 1976) 35(26):2259-2265. doi:10.1097/BRS.0b013e3181cb8828

67. Henriksson H, Thornemo M, Karlsson C, Hagg O, Junevik K, Lindahl A, Brisby H (2009) Identification of cell proliferation zones, progenitor cells and a potential stem cell niche in the intervertebral disc region: a study in four species. Spine (Phila $\mathrm{Pa}$ 1976) 34(21):2278-2287. doi:10.1097/BRS.0b013e3181a95ad2

68. Sakai D, Nakamura Y, Nakai T, Mishima T, Kato S, Grad S, Alini M, Risbud MV, Chan D, Cheah KS, Yamamura K, Masuda K, Okano H, Ando K, Mochida J (2012) Exhaustion of nucleus pulposus progenitor cells with ageing and degeneration of the intervertebral disc. Nature Commun 3:1264. doi:10.1038/ncomms2226

69. Cappello R, Bird JL, Pfeiffer D, Bayliss MT, Dudhia J (2006) Notochordal cell produce and assemble extracellular matrix in a distinct manner, which may be responsible for the maintenance of healthy nucleus pulposus. Spine (Phila Pa 1976) 31(8):873-883. doi:10.1097/01.brs.0000209302.00820.fd

70. Aguiar DJ, Johnson SL, Oegema TR (1999) Notochordal cells interact with nucleus pulposus cells: regulation of proteoglycan synthesis. Exp Cell Res 246(1):129-137. doi:10.1006/excr.1998.4287

71. Erwin WM, Ashman K, O’Donnel P, Inman RD (2006) Nucleus pulposus notochord cells secrete connective tissue growth factor and up-regulate proteoglycan expression by intervertebral disc chondrocytes. Arthritis Rheum 54(12):3859-3867. doi:10.1002/ art. 22258

72. Erwin WM, Islam D, Inman RD, Fehlings MG, Tsui FW (2011) Notochordal cells protect nucleus pulposus cells from degradation and apoptosis: implications for the mechanisms of intervertebral disc degeneration. Arthritis Res Ther 13(6):R215. doi:10. $1186 / \mathrm{ar} 3548$

73. Leung V, Lim F, Hung S, Tuan R, Chan D, Cheung K Defining the phenotype and molecular signatures of notochordal nucleus pulposus cells. In: World Forum for Spine Research (WFSR 2010): The Intervertebral Disc, Montreal, Canada, 5-8 July 2010

74. Chen J, Jing L, Gilchrist CL, Richardson WJ, Fitch RD, Setton LA (2009) Expression of laminin isoforms, receptors, and binding proteins unique to nucleus pulposus cells of immature intervertebral disc. Connect Tissue Res 50(5):294-306. doi:10.1080/ 03008200802714925

75. Chen J JL, Richardson WJ, Brown L, Setton LA (2007) Gene expression profiling reveals age and zonal-specific differences in intervertebral disc tissues during ageing. Trans Orthop Res Soc 
76. Tang X, Jing L, Chen J (2012) Changes in the molecular phenotype of nucleus pulposus cells with intervertebral disc aging. PLoS One 7(12):e52020. doi:10.1371/journal.pone.0052020

77. Gilchrist CL, Francisco AT, Plopper GE, Chen J, Setton LA (2011) Nucleus pulposus cell-matrix interactions with laminins. Eur Cell Mater 21:523-532

78. Chen J, Yan W, Setton LA (2006) Molecular phenotypes of notochordal cells purified from immature nucleus pulposus. Eur Spine J 15(Suppl 3):303-311. doi:10.1007/s00586-006-0088-x

79. Tang X, Jing L, Setton L, Richardson W, Isaacs R, Fitch R, Brown C, Chen J (2013) Identifying the molecular phenotype of cells in the human intervertebral disc reveals the existence of a unique notochordal-like cell population. In: Orthopaedic Research Society 2013 Annual Meeting, San Antonio, Texas

80. Rajasekaran S, Vidyadhara S, Subbiah M, Kamath V, Karunanithi R, Shetty AP, Venkateswaran K, Babu M, Meenakshi J (2010) ISSLS prize winner: a study of effects of in vivo mechanical forces on human lumbar discs with scoliotic disc as a biological model: results from serial postcontrast diffusion studies, histopathology and biochemical analysis of twenty-one human lumbar scoliotic discs. Spine (Phila Pa 1976) 35(21): 1930-1943. doi:10.1097/BRS.0b013e3181e9a156

81. Hristova GI, Jarzem P, Ouellet JA, Roughley PJ, Epure LM, Antoniou J, Mwale F (2011) Calcification in human intervertebral disc degeneration and scoliosis. J Orthop Res 29(12):1888-1895. doi:10.1002/jor.21456

82. Hunter CJ, Matyas JR, Duncan NA (2003) The three-dimensional architecture of the notochordal nucleus pulposus: novel observations on cell structures in the canine intervertebral disc. J Anat 202(Pt 3):279-291

83. Hunter CJ, Matyas JR, Duncan NA (2004) Cytomorphology of notochordal and chondrocytic cells from the nucleus pulposus: a species comparison. J Anat 205(5):357-362. doi:10.1111/j.00218782.2004.00352.X

84. Erwin WM (2008) The notochord, notochordal CELL and CTGF/ $\mathrm{CCN}-2$ : ongoing activity from development through maturation. J Cell Commun Signal 2(3-4):59-65. doi:10.1007/s12079-0080031-5

85. Matsunaga S, Nagano S, Onishi T, Morimoto N, Suzuki S, Komiya S (2003) Age-related changes in expression of transforming growth factor-beta and receptors in cells of intervertebral discs. J Neurosurg 98(1 Suppl):63-67

86. Fujita N, Miyamoto T, Imai J, Hosogane N, Suzuki T, Yagi M, Morita K, Ninomiya K, Miyamoto K, Takaishi H, Matsumoto M, Morioka H, Yabe H, Chiba K, Watanabe S, Toyama Y, Suda T (2005) CD24 is expressed specifically in the nucleus pulposus of intervertebral discs. Biochem Biophys Res Commun 338(4): 1890-1896. doi:10.1016/j.bbrc.2005.10.166

87. Gabr MA, Jing L, Helbling AR, Sinclair SM, Allen KD, Shamji MF, Richardson WJ, Fitch RD, Setton LA, Chen J (2011) Interleukin-17 synergizes with IFNgamma or TNFalpha to promote inflammatory mediator release and intercellular adhesion molecule-1 (ICAM-1) expression in human intervertebral disc cells. J Orthop Res 29(1):1-7. doi:10.1002/jor.21206

88. Le Maitre CL, Richardson SM, Baird P, Freemont AJ, Hoyland JA (2005) Expression of receptors for putative anabolic growth factors in human intervertebral disc: implications for repair and regeneration of the disc. J Pathol 207(4):445-452. doi:10.1002/ path. 1862

89. Urano T, Narusawa K, Shiraki M, Usui T, Sasaki N, Hosoi T, Ouchi Y, Nakamura T, Inoue S (2008) Association of a single nucleotide polymorphism in the insulin-like growth factor-1 receptor gene with spinal disc degeneration in postmenopausal Japanese women. Spine (Phila Pa 1976) 33(11):1256-1261. doi:10.1097/BRS.0b013e3181715304

90. Tolofari SK, Richardson SM, Freemont AJ, Hoyland JA (2010) Expression of semaphorin $3 \mathrm{~A}$ and its receptors in the human intervertebral disc: potential role in regulating neural ingrowth in the degenerate intervertebral disc. Arthritis Res Ther 12(1):R1. doi:10.1186/ar2898

91. Caulin C, Ware CF, Magin TM, Oshima RG (2000) Keratindependent, epithelial resistance to tumor necrosis factor-induced apoptosis. J Cell Biol 149(1):17-22

92. Hayashi $\mathrm{S}$, Taira $\mathrm{A}$, Inoue $\mathrm{G}$, Koshi $\mathrm{T}$, Ito $\mathrm{T}$, Yamashita $\mathrm{M}$, Yamauchi K, Suzuki M, Takahashi K, Ohtori S (2008) TNFalpha in nucleus pulposus induces sensory nerve growth: a study of the mechanism of discogenic low back pain using TNF-alphadeficient mice. Spine (Phila Pa 1976) 33(14):1542-1546. doi:10. 1097/BRS.0b013e318178e5ea 